\title{
Adults' readiness for online learning in the Czech Republic and Latvia (digital competence as a result of ICT education policy and information society development strategy)
}

\author{
Evija Mirḳe ${ }^{1}$, Eva Kašparová ${ }^{2}$, Sarma Cakula ${ }^{3}$ \\ ${ }^{1}$ Distance Education Study Centre, Riga Technical University \\ ${ }^{2}$ University of Economics in Prague, Czech Republic \\ ${ }^{3}$ Vidzeme University of Applied Sciences, Latvia
}

\section{Article Info}

Received Dec 31 2018

\section{eyword:}

Adult learning

The Czech Republic

Digital competence

Latvia

Lifelong learning

Online learning

\begin{abstract}
The study examined adults' readiness for online learning in the Czech Republic and in Latvia. This paper describes and compares the research results in the Czech Republic and Latvia. The outcomes of the study show that there is no statistically significant difference in adults' readiness to study online between both countries. Statistically significant differences were found in the Czech Republic - adults in the age group 18-29 had higher results in the "Readiness to study online", while adults in the age group 50-58 had the lowest result. Also statistically significant differences were found in relation to previous activities - people, who had enrolled and completed online learning courses previously, had significant higher rate of "Readiness to study online". This was observed both in Latvia and the Czech Republic. Collecting data from online readiness survey tool before the course would give useful information to the faculty to plan specific activities for specific groups of learners, to customize their learning path during the progress of the course.
\end{abstract}

\section{Corresponding Author:}

Evija Mirke,

Distance Education Study Centre,

Riga Technical University,

1 Kronvalda Boulevard, Riga, LV-1010, Latvia.

Email: evija.mirke@edu.rtu.lv

\section{Introduction}

Transition processes in the global economy and politics are ongoing; these include education, research and culture. In the middle of 1990s it had become clear that information and communication technology (ICT) possibilities for transferring and processing information changes the meaning of knowledge. Data $\rightarrow$ information $\rightarrow$ knowledge connection had been created, and it significantly changed the social and economic development of the society [1], [2].

Term "digital competence" in European Union (EU) is viewed as consisting of five key competence areas, and people should have competence in all the areas to fully take part in the social activities, to reach their goals at work, education, and suchlike [3]:

- Information and data literacy;

- Communication and collaboration;

- Digital content creation;

- Safety;

- Problem solving. 
Table 1. Adults' participation rate in education and training (last 4 weeks) [4]

\begin{tabular}{cccc}
\hline GEO & 2008 & 2012 & 2017 \\
\hline EU, current composition & 9.5 & 9.2 & 10.9 \\
The Czech Republic & 8.0 & 11.1 & 9.8 \\
Latvia & 6.9 & 7.2 & 7.5 \\
\hline
\end{tabular}

Digital competence is one of the eight key competences for lifelong learning strategies in European Competence Framework [5], [6]. In the information age, where technology is a part of our everyday life, the digital competence is "both a requirement and right of citizens, if they are to be functional in today's society" [7].

In this article term "digital competence" is used to describe individual's skills related to the effective and useful use of ICT, whereby according to Recommendation of the European Parliament "digital competence involves the confident and critical use of Information Society Technology (IST) for work, leisure and communication. It is underpinned by basic skills in ICT: the use of computers to retrieve, assess, store, produce, present and exchange information, and to communicate and participate in collaborative networks via the Internet" [8]. Digital competence is an important factor to live a successful life in the knowledge society, to be an effective adult learner in lifelong learning activities [9].

In this article authors describe the development of information society in two countries - the Czech Republic and Latvia. ICT development and adults' digital competence will be characterized with data from the Central Statistics Bureau of each country. This will give a view over the historic development.

Internet availability and usage are the very technological basis for studying online. In 2016 the Czech Republic was in the 9th place in the world by the Internet speed - it was $17.8 \mathrm{Mbps}$ on average, and Latvia was in the 6th place with the average Internet speed of $18.3 \mathrm{Mbps}$. At that moment it was three times the world average [9].

When describing lifelong learning habits, adult learners in Latvia, in comparison to the Czech Republic, have been more passive in terms of involving in lifelong learning (Table 1):

- In 2008 in Latvia the number of the adults (age 25-64) involved in lifelong learning was 6.9\%, in $2017-7.5 \%$ of adults were involved in any lifelong learning activity [10];

- In 2008 in the Czech Republic 8\% of adults (age 25-64) were involved in any lifelong learning activity, in 2014 their amount was $11.1 \%$, and in $2017-9.8 \%$ [11].

Thus, adults' participation in education and training activities is one of challenges for Latvia and the Czech Republic. The goal of the Education and Training 2020 Programme is to reach $15 \%$ adult participation rate in lifelong learning activities [10].

Involving men in lifelong learning is another challenge for Latvia - during the last 4 weeks from the survey (Eurostat data) $4.1 \%$ of men had participated in any lifelong learning activity in 2011; in 2017 their number had reached $6 \%$ (see Table 1). At the same time $6.5 \%$ of women had participated in education and training activities in 2011, and $8.8 \%$ of women in 2017 [12].

In the Czech Republic adult (age 26-64) participation rates in education and training are higher, but have decreased during the last years. In 2011 participation of males was $11.4 \%$, and in $2017-9.6 \%$ respectively, and participation of females also had decreased from 11.9\% in 2011 to $10.0 \%$ in 2017 (Table 1) [12], [13].

\section{Aim and methodology}

The aim of this research paper is to investigate the information society development strategies' and educational policies' impact on adults' digital competence development in the Czech Republic and Latvia, and adults' readiness for online learning and differences in results depending upon respondents' demographic characteristics.

In order to compare legislation on the information society development in the country and to analyse adults' readiness to learn online respectively, two European Union (EU) countries were selected - the Czech Republic (CZ) and Latvia (LV).

Researchers find historical and political similarities as both nations share common history, though economically and politically each has its own course and development. To mention some of the important dates in the history of Latvia and the Czech Republic - after the World War I, in 1918, both the Czech 
Republic and Latvia declared their independence, both countries were annexed by other armies (Germany and Soviet Union), in nineties of the nineteenth century both restored their independence, and today both are part of The North Atlantic Treaty Organization (NATO) and EU [14] [15] [16].

After doing a research on several online learning assessment surveys, researchers selected the TOOLS questionnaire, created by $\mathrm{PhD}$. M.S. Kerr [17]. The measure is constructed from 45 questions emphasizing self-regulation and independent learning. It was designed to predict the student's success in learning online [18]. There were several reasons why this measure was selected for our research:

- TOOLS questionnaire and scoring scheme are open source and easy to be replicated [18].

- The measure, according to its authors [19] has a simple and stable structure, its construct and criteria have been validated, it has proved to be test-retest reliable.

In Latvia the questionnaire was distributed online in the beginning of 2017; in the Czech Republic it was distributed in May 2017.

The original questions were adapted to specifics of each country, some questions were modified and some new questions were added to the survey for further research needs. The five sections of the survey consisted of 48 Likert-type questions with a range from one (strongly disagree) to five (strongly agree).

After the survey was finished, all data was gathered in a database, a new variable "country" was introduced and the data was processed with IBM Statistical Package for the Social Sciences (SPSS $®$ ) software Version 20 [20].

Reliability statistics was performed (Cronbach's alpha) for all questions, and it was .867 for the answers from Latvia, and .937 for the Czech Republic.

Statistical analysis. The survey consisted of 48 questions in five blocks according to its developers [17]. All individual questionnaires were summarized to obtain groups of variables according to the blocks of questions respectively.

Descriptive statistics. For all study variables descriptive statistics was performed. For group variables author presented the amount and percent participants in each group. For continuous variables author presented mean and standard deviation if the variable distributed normally, while for the variables that did not distribute normally author presented median values as well as minimal and maximal values. All methods and types of statistical data analysis have been chosen accordingly to the specifics of the data gathered.

Univariate analysis of variance. To evaluate what were the differences between countries and among different groups of respondents, univariate analysis of variance was performed, to assess differences in gender and country a t-test of Mann-Whitney test was performed. One-way ANOVA was conducted to find any differences between age groups and place of living.

Correlation analysis. To investigate the relationships between individuals' readiness for online learning and their digital skills, academic skills, independent learning skills, dependent learning skills and their need for distance studies, correlation analysis was performed by calculating Spearman's rho. The results showed which set of skills had greatest positive correlation with the individuals' readiness to study online.

\section{Literature review}

In this chapter authors will investigate the factors of successful lifelong learning. Adults' digital competence in each country will be analysed as well as countries' policies in ICT education and information society development strategies.

\subsection{Lifelong learning}

Lifelong learning has great impact on the society development. Knowledge acquired in schooling process is of great importance, however, the main aspects of knowledge today are that it is inevitably changing, portable, transnational and not tied to any country [21]. Personal experience plays important role in life, it is closely connected with education and as such it is part of life-long learning concept [22]. Adults' learning is one of the top priorities in the European Commission's lifelong learning policy. It is considered very important for personal development and social inclusion as well as a basis for individuals' employability and competitiveness in the job market [23]. Being competitive in the long term in future is also important for an 
individual to live a successful and happy life - circumstances change fast and people have to learn both hard skills and soft skills all life-long.

In 2016 in the "Adult Education Survey" released by Eurostat, the main obstacles for adults to participate in education and training activities in Latvia and the Czech Republic in comparison to EU were: the main obstacles in the Czech Republic for adults to participate in education and training were: no need to further education or training $(68.9 \%)$, other personal reasons $(11.4 \%)$, family reasons $(7.3 \%)$, followed by health/age (2.9\%), schedule $(2.5 \%)$ and costs $(2.4 \%)$ [24].

In Latvia as the main reasons not to participate in learning were: no need to further education/training $(44.4 \%)$, costs $(14.6 \%)$, schedule $(9.5 \%)$, cannot find a suitable offer $(7.2 \%)$, family reasons $(7.1 \%)$, other personal reasons $(6.1 \%)$, health or age $(5.1 \%)$, distance (2.7\%) and lack from employer (1.9\%) [24].

Online/distance learning is one of the solutions for people, who face obstacles (above) in their learning, and there are variations on how the learning can be organized to fit students' needs. Neidorf (2012) mentions some of the most popular forms of web-based education available today: (1) correspondence courses; (2) webinars; (3) synchronous or asynchronous online classes/courses; (4) virtual teams working on the same topic; (5) interactive videos; (6) downloadable e-books with e-mail interaction with learners and suchlike [25].

Distance learning becomes more and more popular due to several reasons, e.g., geographical location of the students and/or faculty - with help of online learning it is possible to deliver a course for students all over the world with highly qualified faculty and minimizing trainers' and topic experts' airport time, meaning they can expand their reach, offering more classes (and earning more) if they don't spend so much time travelling. It is also more cost-saving than traditional in-class education both for the education establishment and for the students. Universities, associations, corporate training departments, and suchlike. - all of them see the value of offering online courses and search creative and confident instructors, who know the specifics of online learning and who know what tools to use and when [25].

It is important to recognize that lifelong learning is there to stay, and educators share the responsibility to motivate adults who participate in education and training activities. Susan Wallace (2017): "In these times when we are encouraged to see lifelong learning as the norm - when the rate of technological advance creates the need for regular re-skilling and updating, and when there is concern over the level of vocational qualifications and basic skills in the adult population - it is more important than ever that we should find ways to keep adult learners motivated" if they have taken the responsibility and enrolled in the course [26].

One of the key tasks of the education system in the Czech Republic has also been the development of the area of lifelong learning. The Lifelong Learning Strategy of the Czech Republic from 2007 highlighted the low computer literacy of the elderly population, which limits the development of lifelong learning. Czech households owned and used ICT to a lesser extent than the other European countries in these years as well. Therefore, the Strategy focused on tertiary education, where it recommended greater support for distance learning through ICT. The other reason of focusing on tertiary education lies in the offer of appropriate study programs and the possibilities of universities to prepare distance learning for adults supported by ICT.

\subsection{Adult learners' behaviour in online learning environment}

Neidorf (2012) and Wallace (2017) emphasize key characteristics of most adult students and suggests any adult educator take them into account when creating online learning experience [25] [26]:

- Personal history and experience.

- Preferred learning style

- Other responsibilities and time.

- Motivation to learn.

- Psychology.

\subsection{Information society development strategies and ICT in education in $\mathrm{CZ}$ and $\mathrm{LV}$}




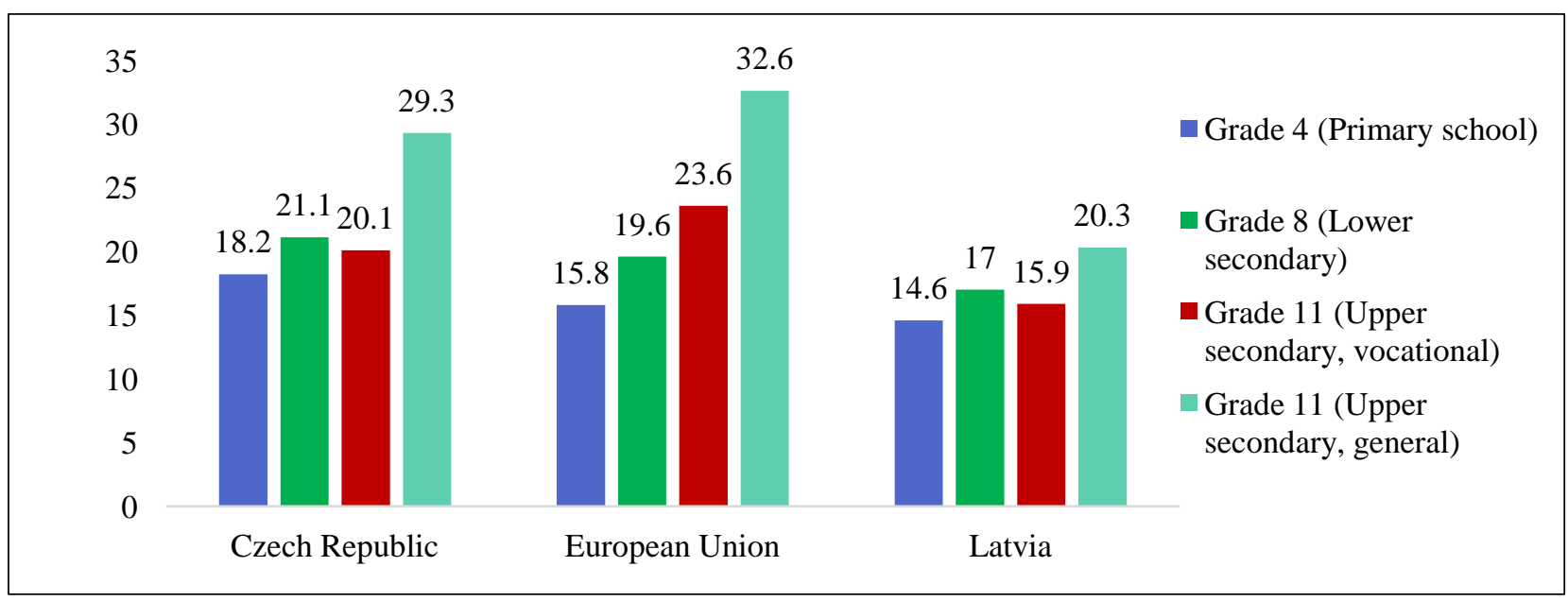

Figure 1. Computers for educational purposes in 2012 (number per 100 pupils), [28]

In general country's place in the global society of telecommunications can be characterized by annual ICT development index (IDI), which has been published since 2009 and can be used to monitor developments in ICT and compare them between countries. The index is calculated in three sub-scales [27]:

- ICT readiness (infrastructure, physical access);

- $\quad$ ICT use (intensity of Internet usage);

- ICT capability (skills or capabilities to use ICT) [27].

In 2017 Latvia was in the 35th place with IDI 7.26 (40th place in 2016 with IDI 7.05), and The Czech Republic was in 43rd place with IDI 7.16 (39th place in 2016 with IDI 7.06) [27]:

Data about computers for educational purposes in each country of this research and European Union in 2012 (Figure 1) shows differences in the numbers - e.g., in primary school there were 18.2 computers per 100 pupils in the Czech Republic, 14.6 - in Latvia (in EU 15.8 respectively); in upper secondary school there were 29.3 computers per 100 pupils in the Czech Republic, 20.3 - in Latvia and 32.6 in EU respectively [28].

The planned and systematic promotion of the use of ICT in the education process has begun in the Czech Republic since the end of the nineties of the twentieth century.

By the early nineties of the twentieth century, Czech education had to deal with considerable delays in the implementation of IT technologies in education. The computer equipment was very limited and the content of the subject Informatics and Computer Technology has narrowed in most cases on algorithmization and programming.

The State Information Policy Concept of 1999, which underlined the importance of ICT-enabled education and the use of ICT in society, has already clearly indicated the direction and objectives of further development in its subtitle "The Way to the Information Society".

The information literacy as a one of the key priorities of The State Information Policy Concept of 1999 has become a big challenge for the existing educational system [29]. The Czech Republic has grasped the importance of ICT in the contemporary society, and therefore the schools have been gradually equipped with the necessary hardware and software. The educational institutions have fulfilled in varying degrees the most important strategic goal of the concept, i.e. the ability to work with ICT (both teachers and students) as well as the second very important goal i.e. the integration of ICT into teaching in line with the curriculum of subjects. Education had to adapt gradually the new societal needs and the new role it played in the information society [30].

The next stage of ICT usage development in education started at 2004, when the Government of the Czech Republic approved a new State Information and Communication Policy with a subtitle e-Czech. The most important step forward was the emphasis on the importance of communication at work with and through IT. The enhancing of ability of schools to use ICT, eLearning technology and educational software, including their introduction to teaching were the main objectives of governmental education concept. A computer equipment was in almost 99.6\% of schools in the Czech Republic in 2005. 
Table 2. Human Capital indicators in DESI 2018, \%

\begin{tabular}{|c|c|c|}
\hline Characteristics & CZ & LV \\
\hline Internet users & 81 & 78 \\
\hline At least basic skills & 60 & 48 \\
\hline ICT Specialists & 3.5 & 2.2 \\
\hline STEM graduates & 17.2 & 12.7 \\
\hline
\end{tabular}

The standardization of registration and evaluation of learning objects as well as the standardization of communication services for schools and the support of e-learning tools took place concurrently. The systematic training of teachers on the level of basic informational literacy was in the centre of attention therefore in parallel.

One of the key tasks of the education system has also been the development of the area of lifelong learning. The Lifelong Learning Strategy of the Czech Republic from 2007 highlighted the low computer literacy of the elderly population, which limits the development of lifelong learning. Czech households owned and used ICT to a lesser extent than the other European countries in these years as well. Therefore, the Strategy focused on tertiary education, where it recommended greater support for distance learning through ICT. The other reason of focusing on tertiary education lies in the offer of appropriate study programs and the possibilities of universities to prepare distance learning for adults supported by ICT.

The systematic process of informatization, the unprecedented growth in the speed and a quantity of information production and distribution and the increased role of ICT-assisted knowledge processes, systems, and networks [31] in the whole society focused especially on the development of information services providing in the Czech Republic in the next years.

The present new Digital literacy strategy for the period 2015-20 linked to the European strategies and national programs is a joint initiative of the Ministry of Education, Youth and Sports (MŠMT) and the Ministry of Labour and Social Affairs (MPSV). The strategy adopts a comprehensive approach to achieving digital literacy. The Czech digital literacy strategy defines the main fields that should be in the centre of attention and in which direction it is necessary to go. It covers most aspects of how ICT influences individuals in all aspects of life: employment, entrepreneurship, social inclusion, family life, public electronic services, and education and training. Systematic support of education and learning through digital technologies is still a prerequisite for digital literacy in the Czech Republic. Fulfilling this goal leads to massive support of education through digital technologies and open educational resources [32].

In the latest Digital Economy and Society Index (DESI) report, (2018) the Czech Republic was ranked in the 17th place with score 63.9, and Latvia was 19th with the score 50.8 (in comparison - EU score was 54.0).

Human capital (comprized of the Internet Use, basic digital skills, Advanced skills and Development) is one of DESI dimensions. In 2018 the Czech Republic was ranked in the 13th place with score 55.1, while Latvia was only 23rd with score 43.8 (EU score 56.5) with great differences (Table 2Error! Reference source not found.) [33]:

In the table DESI published results are shown and differences can be observed - in the Czech Republic there are more individuals with the basic digital skills. The growth of the number of Internet users in both countries is shown in the graph (Figure 1), where changes in the amount of frequent Internet users in the Czech Republic can be observed - in 2012/2013 number of people using Internet every day or almost every day is growing rapidly [34].

In Latvia the Education Development Guidelines for 2014-2020 have been adopted, addressing ICT use for developing digital skills, development of e-skills. National Coalition for digital skills and jobs has been formed and projects started with EU financial support, however, these activities have recently started and noticeable improvement in the digital skills of citizens is to come in future [33].

The Czech Republic has announced development of citizens' digital competences a priority. Digital Education Strategy has been established with great focus on computational thinking, open education both for teachers and children, and digital literacy in general. PRIM (Podpora rozvíjení informatického myšlení) project should be mentioned [35] as an example of country's Digital Education Strategy - the project is aimed to develop computational thinking and activities involve creating MOOC courses, developing educational materials for all educational levels, organising lessons in universities, in-service courses for teachers, and suchlike.

In 2017 the Czech Republic had made great progress. The government approved action plan "Society 4.0" together with the principles for digital-friendly legislation. Priority tasks have been formulated with respect to 
the digital technologies' impact on the society and economy, labour market, education, industry, computerisation of public administration and others [33].

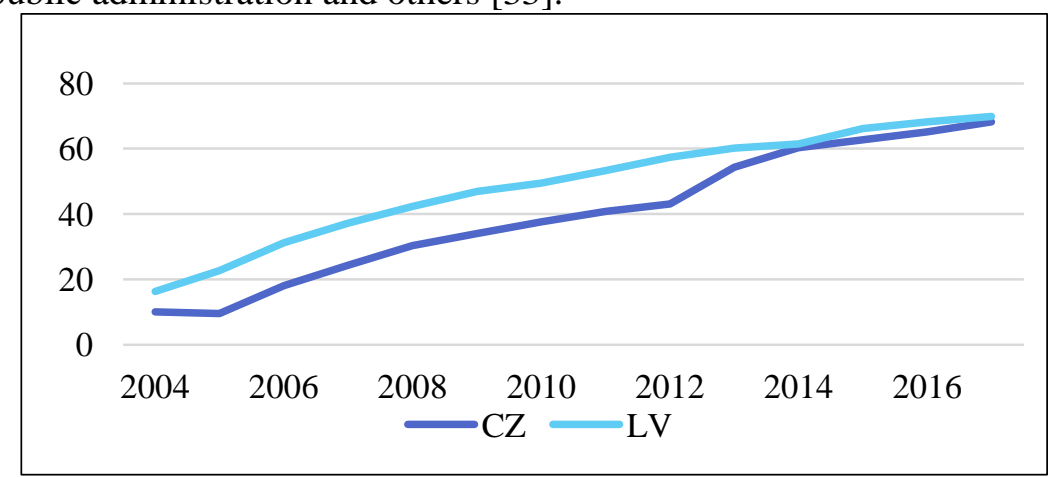

Figure 1. Growth of number of frequent internet users (every day or almost every day) [34]

Latvia had made progress in connectivity and digital public services areas, however, experts admit that digital skills' improvement has to become a priority to improve the productivity and to create more inclusive labour market. Information Society Development Guidelines for 2014-2020 is the current legislative document approved by the Latvian government [33], [36].

\subsection{ICT education in Latvia}

Teaching the subject called "Informatics" (the name has changed several times) has a long history in Latvia. First during the sixties in the twentieth century teaching Informatics was introduced in five schools under the name "Computing mathematics and programming" with one lesson per week. In reality it could mean only one visit per year to a computing centre to show what a computing machine looks like - there were no computers in those schools. Almost 20 years later a new subject "Career Education" (or "Handwork") was introduced in some schools with special classes for mathematics and physics. Reference [37] shows that the programming was limited to algorithmization on paper - no computers were supplied.

In 1991 a reform was introduced - upper secondary school programme was taught in "courses" and pupils could choose what to learn. "Informatics" was no longer an obligatory subject, therefore many pupils chose other - easier - subjects. It meant that some pupils did not learn ICT skills necessary for their future. Statistics showed that in 1996 only $29 \%$ of the pupils in grade 12 had chosen to learn the elementary course of the "Applied Informatics", 25\% had chosen the advanced course. It means that the rest $-46 \%$ of the 12th grade pupils - did not learn any ICT skills at all [37].

In $20^{\text {th }}$ century nineties at least $50 \%$ of the teachers of Informatics had only the basic knowledge of computers, many teachers were self-taught in computers, some teachers did not have higher education (they had just graduated from the secondary school or gymnasium), many teachers had the degree in IT, but they lacked practical skills. Computers were old and out of date [38].

\subsection{Development of adults' digital skills in Latvia}

In 1997 a government project called LIIS (Latvian Education Informatization System) was commenced within the governmental project "National programme Informatics, which was coordinated by the Ministry of Transport [39]. LIIS was built to cover all the aspects in education - computers and infrastructure, information services, management, education content, teaching aids (workbooks, interactive content, online tests, or similar) and teacher (users) training [40], [41]. Due to financial problems, government did not transfer all the planned funds to LIIS project, due to which informatization in schools was delayed. In 1999 Latvia in terms of amount of computers in schools already lagged behind the nearest neighbours, Estonia and Lithuania [42].

To give access to computers and to teach ICT skills to reduce the digital divide in the society a project called "Father's Third Son" (hero from Latvian fairy tales - author) was implemented by State Agency "Culture Information Systems". Librarians were taught computer skills and were able to teach library visitors, to consult them on the computer use. People could use Internet free of charge in the libraries for studies, work and entertainment. It was the largest long-term project, which lasted for ten years and reached the goals set library users recognized it as useful, number of Internet users in the public libraries had grown, librarians had become skilful computer users, people from all the country, especially, rural areas and with low income had 
had access to computers. In a survey conducted in 2011 every fifth respondent answered they used library Internet because they had no other alternatives. $95 \%$ of the libraries offered individual consultations $-80 \%$ had consulted senior citizens, $79 \%$ - unemployed, $58 \%$ - children, $41 \%$ - self-employed, $37 \%$ - young parents with small children. More than half of the libraries had organized group trainings $-37 \%$ for seniors, $29 \%$ for unemployed, $20 \%$ for children [43].

Other public and private activities have taken place, however, authors did not find any proof of successful implementation and good results after these events.

\section{Research results}

The first survey was conducted in Latvia; 200 answers were collected. Respondents were adults - Internet users (age 18-65). The answers were collected during January-February, 2017. In the Czech Republic the questionnaire was published on the websites of several educational institutions, which includes that respondents were mainly students or faculty members of some of the educational institutions offering any kind of online course/s. Researchers took this fact into account when interpreting the results.

Descriptive statistics

Latvia. sample consisted of 200 participants, $75.5 \%$ of them were women, mostly lived in Riga, the capital (53.5\%), and mostly from age group 30-39 (46.5\%), followed by 40-49 (23\%), 18-29 (17.5\%) and 50-59 $(11.5 \%)$, only $1.5 \%$ were $>60$ years of age. Highest number of participants had never taken any online learning course $(45.5 \%)$, very small amount of people $(7 \%)$ had successfully completed more than three online learning courses, $25.5 \%$ had completed one or two courses, and $22 \%$ of respondents had started but due to various reasons never completed any online course.

The Czech Republic. Study sample consisted of 258 participants, $50.4 \%$ of them were men, mostly lived in Prague, the capital (35.9\%), and mostly from age group 18-29 (38.4\%), followed by 30-39 (31.4\%), 40-49 $(17.4 \%)$ and $50-59(11.2 \%)$, only $1.6 \%$ were $>60$ years of age. Highest number of participants had never taken any online learning course (51.9\%), very small amount of people (1.6\%) had started but due to various reasons never completed any online course, $27.1 \%$ had completed 1 or 2 courses and $19.4 \%$ had successfully completed more than 3 online learning courses.

Univariate analysis of variance

To find statistically significant differences univariate analysis of variance (ANOVA) was carried out as it provides a useful tool to test the factors and their interrelations (Anderson after Underwood, 2001) [44].

\subsection{Differences between countries}

Statistically significant difference between countries in "Readiness to study online" were not found $(\mathrm{t}=-0.82$ $\mathrm{p}=0.41)$.

\subsection{Differences among age groups}

Statistically significant differences among age groups in "Readiness to study online" were found in the Czech Republic $(\mathrm{F}=3.56 \mathrm{p}<0.01)$. Adults in the age group 18-29 had higher results in the "Readiness to study online, while adults in the age group 50-58 had the lowest result.

No statistically significant differences among age groups were found in Latvia $(F=0.65, p=0.63)$.

\subsection{Differences between genders}

Statistically significant differences between genders in "Readiness to study online" were not found in any of the respective countries $(\mathrm{t}=-0.91, \mathrm{p}=0.36(\mathrm{CZ}), \mathrm{t}=1.48, \mathrm{p}=0.14(\mathrm{LV}))$.

\subsubsection{Differences by the previous experience with online learning courses}

Statistically significant differences in "Readiness to study online" among groups in relation to the previous experience with online learning were found both in the Czech Republic $(F=15.87 \mathrm{p}<0.01)$ and in Latvia $(F$ $=8.02 \mathrm{p}<0.01$ ).

In the Czech Republic respondents with higher results in "Readiness to study online", had completed more than three courses online (mean $=179.34$ ) or more than two courses online (mean 172.30). Respondents with 
the lowest results in "Readiness to study online" had started but never completed a course $($ mean $=157.25)$ and/or had never tried to learn online (mean $=160.12$ ).

In Latvia respondents who had completed more than three courses online had higher results in "Readiness to study online" (mean $=179.93)$, followed by respondents who had completed more than two courses online $($ mean $=169.27)$, while respondents with lower results had never taken any e-learning course $($ mean $=162.57)$ or started but never completed any course online (mean $=163.61)$.

\subsection{Differences among place of living}

Statistically significant differences among groups in "Readiness to study online" in relation to the place of living were not found $(\mathrm{F}=0.59, \mathrm{p}=0.67(\mathrm{CZ}), \mathrm{F}=1.68, \mathrm{p}=0.16(\mathrm{LV}))$.

\section{Conclusions}

In 2012 the Czech Republic had already equipped more schools with computers than Latvia (and EU average). The Czech Republic introduced first information society guidelines in 1999, Latvia - in 2006. In the number of Internet users', the Czech Republic was behind Latvia until 2014, and during the last years the number of Internet users is above EU average.

Statistically significant differences among age groups were found in the answers of respondents from the Czech Republic where adults in the age group 18-29 had higher results in the "Readiness to study online", while adults in the age group 50-59 had the lowest result.

People, with higher results in "Readiness to study online", had completed more courses online, while people with the lowest results had started but never completed a course or had never tried to learn online. As there was a statistically significant difference among these groups $(\mathrm{p}<0.01)$ researchers assume that there is a relationship between the results acquired from online readiness survey and respondents' motivation and ability to learn online and complete the learning course.

\section{Discussion and further developments}

Consequency in implementing information society strategy and policy of ICT introduction in education has ranked the Czech Republic higher in EU member states' ranking in terms of citizens' digital competence, while changes and education reforms without ICT as a priority in the development of the information society has left Latvia behind Czech Republic in several positions.

The Czech Republic has announced development of citizens' digital competences a priority. Digital Education Strategy has been established with great focus on computational thinking, open education both for teachers and children, and digital literacy in general. In 2017 the Czech Republic government approved action plan "Society 4.0" and principles for digital-friendly legislation.

In Latvia digital skills' improvement is not the highest priority - Information Society Development Guidelines for 2014-2020 is the latest document approved by the Latvian government in 2013.

Authors of the TOOLS survey [17], Kerr, Rynearson \& Kerr (2006) had tested the TOOLS instrument in online courses with students at a public university in the United States of Americas and they found that only the academic skills was a significant predictor of online course grades [45]. However, we found that there were statistically significant differences in relation to different demographic characteristics of the respondents (age).

Even though no significant differences were found in relation to the place of living or gender in this research, additional research should be carried out with larger study sample to test whether place of living, respondents' education level or other characteristics have some impact upon the "Readiness to study online". Due to the limited study sample (458 respondents in total) and not specified audience, we plan to continue the research on adults' readiness to study online to develop several student profiles as regards to their "Readiness to study online" (e.g., professionals in certain business area, municipality officials, medical employees, entrepreneurs, retired people, young people, retired people, and suchlike) to find connections between variables and students' demographical or professional characteristics.

We assume that conducting such an online readiness survey before/in the beginning of the online course would give useful information to the instructors or faculty to plan specific activities for specific groups of learners (e.g., when students become less motivated, when students lack technical knowledge or skills to 
compete a task, or similar), to customize their learning path in the beginning or during the progress of the course.

Collecting data from online readiness survey tool before the course could also help faculty to predict which students could add to the drop-out rate and plan activities, to help them overcome the difficult moments and keep their interest in the course.

\section{Acknowledgments}

This research has been supported by a grant from the European Regional Development Fund (ERFD/ERAF) project "Technology Enhanced Learning E-ecosystem with Stochastic Interdependences - TELECI", Project No.1.1.1.1./16/A/154.

\section{References}

[1] A. Janbicka and E. Karnitis, "Concept of Provision of Scientific and technical Information for Latvia," 1997, p. 12.

[2] E. Karnītis and A. Virtmanis, Broadband in Latvia: Development and Prospects (In Latvian: Platjoslas sakari Latvijā: attīstība un perspektīvas). Rīga: LU Akadēmiskais apgāds, 2015.

[3] "The European Digital Competence Framework for Citizens." Publications Office of the European Union, p. 12, 2016.

[4] Eurostat, "Lifelong learning statistics." [Online]. Available: https://ec.europa.eu/eurostat/statisticsexplained/index.php/Adult_learning_statistics. [Accessed: 29-Jan-2017].

[5] EUR-Lex, "Lifelong learning — key competences." 2016.

[6] LR Izglīīibas un zinātnes ministrija, Adult Education Management Model Implementation Plan 20162020 year (In Latvian: Pieaugušo izglītības pārvaldības modeļa ieviešanas plāns 2016.-2020. gadam). Rīga: LR Ministru kabinets, 2016.

[7] A. Ferrari, "Digital Competence in Practice: An Analysis of Frameworks," Seville, 2012.

[8] EC, "RECOMMENDATION OF THE EUROPEAN PARLIAMENT AND OF THE COUNCIL of 18 December 2006 on key competences for lifelong learning," Off. J. Eur. Union, 2016.

[9] L. Ilomäki, A. Kantosalo, and M. Lakkala, "What is digital competence?," Linked portal. Brussels: European Schoolnet., 2011. [Online]. Available: http://linked.eun.org/web/guest/in-depth3. [Accessed: 28-Feb-2017].

[10] EC, "Education and Training MONITOR 2018 Latvia," 2018.

[11] EC, "Education and Training Monitor 2018 Czech Republic Factsheet," 2018. [Online]. Available: https://ec.europa.eu/education/sites/education/files/document-library-docs/et-monitor-factsheet-2018czechrepublic_en.pdf. [Accessed: 21-Dec-2018].

[12] EC, "Database - Eurostat - Education and training." [Online]. Available: https://ec.europa.eu/eurostat/web/education-and-

training/data/database?p_p_id=NavTreeportletprod_WAR_NavTreeportletprod_INSTANCE_LUWsd X8ute5m\&p_p_lifecycle $=0 \& p \_p \_s t a t e=$ normal \&p_p_mode $=$ view\&p_p_col_id $=$ column-

2\&p_p_col_count=1. [Accessed: 31-Dec-2018].

[13] Eurostat, "Lifelong learning statistics." [Online]. Available: http://ec.europa.eu/eurostat/statisticsexplained/index.php/Lifelong_learning_statistics. [Accessed: 29-Jan-2017].

[14] "Czech Republic country profile - BBC News." [Online]. Available: https://www.bbc.com/news/world-europe-17220018. [Accessed: 26-Dec-2018].

[15] WEB, "Latvia country profile - BBC News." [Online]. Available: https://www.bbc.com/news/worldeurope-17522134. [Accessed: 26-Dec-2018].

[16] "Brief History of the Czech Republic | Embassy of the Czech Republic in Tripoli." [Online]. Available: https://www.mzv.cz/tripoli/en/general_information_about_the_czech/history/index.html. [Accessed: 30-Dec-2018].

[17] M. S. Kerr, "Test of online learning success TOOLS." [Online]. Available: http://www.txwescetl.com/about-distance- ed/for-students/. [Accessed: 26-Jan-2017].

[18] D. E. Lee, "STUDY OF THE PREDICTIVE VALUE OF THE TEST OF ONLINE LEARNING SUCCESS," San Francisko State University, 2016.

[19] M. S. Kerr, K. Rynearson, and M. C. Kerr, "Student characteristics for online learning success," Internet High. Educ., vol. 9, no. 2, pp. 91-105, Apr. 2006. 
[20] "IBM." [Online]. Available: https://www.ibm.com/analytics/spss-statistics-software?mhq=\%27spss statistics\%27\&mhsrc=ibmsearch_a. [Accessed: 18-Dec-2018].

[21] P. F. Drucker, Managing in a Time of Great Change. Oxford, UK: Butterworth-Heinemann, 1997.

[22] A. Kabadayi, "A Suggested In-service Training Model Based on Turkish Preschool Teachers' Conceptions for Sustainable Development," J. Teach. Educ. Sustain., vol. 18, no. 1, pp. 5-15, 2016.

[23] EC, "EU policy in the field of adult learning." [Online]. Available: https://ec.europa.eu/education/policies/eu-policy-in-the-field-of-adult-learning_en. [Accessed: 26-Jan2017].

[24] WEB, "Database - Eurostat." [Online]. Available: https://ec.europa.eu/eurostat/web/digital-economyand-society/data/database. [Accessed: 26-Dec-2018].

[25] R. Neidorf, Teach Beyond Your Reach, 2nd ed. Medford, New Jersey: Information Today, Inc., 2012.

[26] S. Wallace, Motivating Unwilling Learners in Further Education. London, UK: Bloomsbury Education, 2017.

[27] "ITU | 2017 Global ICT Development Index." [Online]. Available: http://www.itu.int/net4/itud/idi/2017/index.html. [Accessed: 26-Dec-2018].

[28] Publications Office of the EU, "EU Open Data Portal," 2018. [Online]. Available: https://data.europa.eu/euodp/en/home. [Accessed: 28-Dec-2018].

[29] "SIP Státní informační politika," 1999. [Online]. Available: www.msmt.cz. [Accessed: 02-Jan-2018].

[30] "SIPVZ Ministerstvo školství mládeže a tělovýchovy. Koncepce státní informační politiky ve vzdělávání.,” 2000. [Online]. Available: www.msmt.cz. [Accessed: 07-Jan-2018].

[31] A.-V. Anttiroiko, "Democratic E-Governance," Encyclopedia of Information Science and Technology, Second Edition Copyright: (․ 2009.

[32] J. Holeček, "Strategie digitální gramotnosti," 2016. [Online]. Available: https://koopolis.cz/sekce/revue-dv/560-strategie-digitalni-gramotnosti. [Accessed: 07-Jan-2018].

[33] EC, "Human Capital, Digital Inclusion and Skills. Digital Economy and Society Index Report 2018." [Online]. Available: https://ec.europa.eu/digital-single-market/en/desi. [Accessed: 31-Dec-2018].

[34] EC, "Digital Economy \&amp; Society - Digital Agenda Scoreboard key indicators." [Online]. Available: $\quad$ https://digital-agendadata.eu/datasets/digital_agenda_scoreboard_key_indicators/visualizations. [Accessed: 31-Dec-2018].

[35] "Podpora rozvíjení informatického myšlení (PRIM), Národní ústav pro vzdělávání." [Online]. Available: http://www.nuv.cz/projekty/prim?lang=1. [Accessed: 29-Dec-2018].

[36] LR Ministru kabinets, About Information Society Development Guidelines 2014-2020 (in Latvian: Par Informācijas sabiedrības attīstības pamatnostādnēm 2014.-2020.gadam). Rīga: Ministru kabinets, 2013.

[37] V. Vēzis, "Informatics in the school (in Latvian: Informātika skolā)," Latvijas Universitāte, 2005.

[38] G. Nagle, "Informatization of education without informatics teachers (In Latvian: Izglītības informatizācija bez informātikas skolotājiem)," 28-Apr-1998.

[39] LR Satiksmes ministrija, National programme "Informatics" (in Latvian: Nacionālā programma "Informātika"). Rīga: LNB, 1999.

[40] J. Bičevskis, "The information society begins in school (in Latvian: Informācijas sabiedrība sākas skolā)," 2002. [Online]. Available: http://providus.lv/article/informacijas-sabiedriba-sakas-skola. [Accessed: 27-Dec-2018].

[41] J. Bicevskis, A. Agnis;, I. Evalds; M. Inga;, S. Uldis; and V. Vezis, "Latvian Education Informatization System LIIS," EMI. Educ. Media Int., vol. 41, no. 1, pp. 43-50, 2004.

[42] G. Nagle, "Slow-downs of education as opposed to rapid technological progress (in Latvian: Izglitīibas lēnie tempi pretstatā straujajam tehnologijas progresam)," Newspaper "Diena," Rīga, 1999.

[43] 'Public Library Development Project 'Third Father's Son' (in Latvian: Publisko bibliotēku attīstības projekts 'Trešais tēva dēls' Kultūras informācijas sistēmu centrs)." [Online]. Available: http://www.kis.gov.lv/projekti/bibliotekam/publisko-biblioteku-attistibas-projekts/. [Accessed: 28Dec-2018].

[44] M. J. Anderson, "A new method for non-parametric multivariate analysis of variance," Austral Ecol., no. 26, pp. 32-46, 2001.

[45] C. Wladis and J. Samuels, "Do online readiness surveys do what they claim? Validity, reliability, and subsequent student enrollment decisions," Comput. Educ., vol. 98, pp. 39-56, Jul. 2016. 